\title{
The uses of equality in an elite school in India: enterprise and merit
}

\author{
Arathi Sriprakash, Jing Qi, Michael Singh
}

Dr Arathi Sriprakash (corresponding author)

University of Cambridge

184 Hills Road

Cambridge, UK, CB28PQ

+441223767512

as621@cam.ac.uk

Dr Jing Qi

Western Sydney University

Locked Bag 1797

Penrith 2751 NSW

Australia

+61416586931

j.qi@westernsydney.edu.au

Professor Michael Singh

Western Sydney University

Locked Bag 1797

Penrith 2751 NSW

Australia

+61247360186

m.j.singh@westernsydney.edu.au

\begin{abstract}
:
This paper examines the different uses of equality in one elite international school in India. We focus on how conceptions of equality can be enrolled into particular scripts of benevolence and gifting through which elite distinctions are constituted and enacted. Our analysis of interviews with students, teachers and parents in the school highlights three dominant and interrelated uses of equality that are examined with respect to entrepreneurial social ideals in contemporary neoliberal India: equality for-profit, equality as deferred, and equality as a differential inclusion of the poor. We call this 'enterprise equality' and consider its performative effects, namely in reconstituting and justifying normative inequality. Enterprise equality does two related things which have significant global consequences: it can function as a process of 'decontestation' - a way to 'block hearing' about alternative political/economic arrangements of equality; and it can reaffirm the cultural rhetoric of the elite as meritorious in their privilege.
\end{abstract}

Keywords: Equality, entrepreneurialism, elite schooling, global citizenship, community service, privatisation 


\section{The uses of equality in an elite school in India: enterprise and merit}

\section{Introduction}

Many elite schools across the world engage in practices of patronage and benefaction, with ideas of altruism being expressed in school policy and curricula through programmes for community service, charity, scholarships, outreach, community engagement and so on. Kenway and Fahey (2015), in their recent study of benefaction in elite schools, reflect that the inequalities of the world are increasingly positioned as the responsibility of the elite to address. Problematically, however, practices of benefaction, service, and other forms of 'gifting' by elite schools reinscribe unequal relations of power between giver and receiver, producing a contemporary - and increasingly global - 'moral aristocracy' (107). Programmes of community service and sponsorship enable elite schools 'to represent themselves as socially responsible institutions and to downplay, even disavow, their well-documented role in reproducing privilege' (112). This raises questions, Kenway and Fahey suggest, about the possibilities of 'absolute altruism' in the elite school context.

Taking up this inquiry, this paper examines the different uses of equality in one elite international school in India. Our analysis shows how conceptions of equality can be enrolled into particular scripts of benevolence and gifting through which elite distinctions - or class strategies - are constituted and enacted. This, we suggest, offers insights into the ways 'equality' can be used as a practice of class closure and legitimation: it justifies a normative inequality through which the advancement of the elite is made the natural order of things. The three dominant uses of equality we discuss in this paper are: equality for profit; equality as deferred; and equality as differential inclusion. We call this 'enterprise equality' and we consider how, in elite schools and beyond, it can 'block hearing' about alternative political/economic arrangements for egalitarian social change, and reaffirm elite subjectivities as meritorious in their advantage.

India has a long colonial and postcolonial history of private benefaction and social service (see for example, Watt 2005) in which the notions of the 'private' and of 'service', and their relationship to the nation, has shifted considerably. Our present analysis is set within the context of public education in India being significantly reconfigured through economic liberalisation and globalisation over the last two and a half decades. The domain of education has seen a marked rise in corporate social responsibility interventions, 
public-private partnerships in policy making and provision, edu-businesses and educational entrepreneurs, and transnational advocacy networks (Kumar, 2012; Nambissan \& Ball, 2010). In 2014 India became the first country to legally mandate corporate social responsibility in which large profitable companies must spend at least two per cent of average net profits on programmes or projects addressing social disadvantage. This has firmly positioned private institutions as primary 'public' actors of social equality. Within more local domains, elite and middle-class 'volunteerism' has gained increasing visibility and legitimacy through programmes for social and educational development (Maithreyi, 2015). This article considers an elite private school's engagements with community service and global citizenship with respect to these broader moves. Our analysis shows how dominant uses of equality in the school can work to 'de-contest' the role of the enterprising private actor - and their maintenance of privilege - in social and educational projects of equality.

The research on which this paper is based examined the community service and global citizenship ('international mindedness') programmes in International Baccalaureate (IB) schools in India, China and Australia (see Sriprakash et al., 2014, in which we offer fuller explanation of the aims and background of the IB 'international mindedness' programme). The comparative study involved semi-structured interviews with 196 parents, teachers, educational managers and senior students, as well as observations of lessons and school events in six schools. We analysed how participants' conceptions of 'equality' were brought to their understandings and justifications of international mindedness and community service. In order to look more closely at participants' notions and uses of equality, our discussions in this paper will focus on one of the schools we studied in India, which we call 'Indian Academy'.

\section{Equality, enterprise, and merit}

Contemporary globalisation and the emergence of new transnational classes of elites are, as van Zanten (2009) has argued, creating new dividing lines and practices in education. Research on elite schooling in a recent Special Issue of this journal, for example, have explored the relationships between national and global dynamics of economics and politics in elite class-making in and across the global north and south (Kenway $\&$ Koh, 2015). The 'new elite' are increasingly diverse, and often their educational institutions are seemingly more 'open' - responding to discourses of affirmative action, rights, and progressive notions of outreach and citizenship (Khan 2011). The diverse new elite are representative of an apparently increasing global social mobility. However, they carry with them the task of maintaining the narrative of meritocracy;

\footnotetext{
${ }^{1}$ Pseudonyms are used for school institutions and individual participants. We conducted interviews with 37 participants in Indian Academy, including 10 students, 19 teachers and 8 parents.
} 
that their rise in contexts of deepening global inequality is associated with their individual talents and efforts (Khan, 2012). This operates as a class strategy that is somewhat less visible than other modes of elite distinction such as consumption and adornment practices (cf. Daloz, 2012). We consider how discourses of 'equality' are put to work in and through the schooling of the 'new elite', particularly with respect to practices of service and benefaction.

Part of our analysis considers how the entrepreneurial motifs in participants' uses of equality produce particular elite subjectivities through which ideologies of meritocracy become legitimised and unquestionable. In the context of post-1991 liberalising India, the ideal of the entrepreneurial, globallyoriented citizen in political and public discourse has shaped aspirations across the class spectrum (Fernandes \& Heller 2006, Gooptu, 2013, Lukose, 2009). As Gooptu (2013, 14) argues in her book on Enterprise Culture of Neoliberal India,

in contemporary India, enterprise culture and the enterprising self are considered to be of central importance in producing both dynamic economic actors for a globalized, liberalised economy and self-governed citizens of a state that is being re-engineered primarily as an enabler of the market.

Smitha Radhakrishnan (2011), in her study of the 'new' transnational class of young Indian IT professionals, examines how the ideology of meritocracy offers a rationalisation for elite classes to connect the development of their personal expertise/entrepreneurialism to the improvement of the nation. She shows how discourses of merit take a particular form, 'rooted in the free-market oriented, individualised language of the knowledge economy' (90). Not only does this conceal the inequalities of the elite educational system in India that these actors have benefited from, and the multiple class and caste strategies used to secure/maintain privilege ${ }^{2}$, but it also produces 'a powerful embodiment of a new India in which each advances according to his or her individual merit rather than according to parochial categories' (90).

Recent work by Subramanian (2015) importantly highlights the somewhat hidden dynamics of caste in such class strategies of meritocracy. She notes in her research on class/caste politics in elite higher education institutions (Indian Institutes of Technology), that there has not been an erosion of caste in India, but rather, "upper-caste claims have been strengthened by transnational mobility and the enhanced value of technical know-how within the late twentieth and early twenty-first century 'knowledge economy" (Subramanian,

\footnotetext{
${ }^{2}$ See for example: Mehendale et al. (2015) for a discussion of the growing significance of middle-class parent lobby groups in India; Vidya \& Sarangapani (2011) on the disproportionate reporting of middle-class interests in education in English-language newspapers; and Vincent \& Menon’s (2011) discussion of middle-class school choice and educational strategies.
} 
2015, 98). She goes on to suggest, "rather than just subaltern identitarianism, then, the leveraging of caste must also be seen as an upper-caste politics that attempts to forestall democratic progress and derives its legitimacy from the global commodification of knowledge" (ibid, 98). It is thus worth emphasising that the analytic category of 'elite' which frames this paper, often associated with social class, is enmeshed too in an upper-caste politics of privilege in India.

In the analysis that follows, we draw on the notion of performativity to trace the effects of elite uses of equality. Performativity, in a Butlerian sense, refers to the 'discursive mode by which ontological effects are installed' (Butler, as cited in Hey 2006). Such an approach compels one to consider, for example, how discourses of the global, entrepreneurial actor in social contexts of volunteerism and privatisation enable particular versions of equality and elite subjectivity to be performed. However, we also take note of Ahmed (2004) who argues that 'performativity' has become banal and overused in academic writing to signify the ways in which something is “'brought into existence' through speech, representation, writing, law, practice or discourse" (51). Ahmed shows how, for example, declarations of 'whiteness' in the supposed aid of antiracism are 'assumed to put in place the conditions in which racism can be transcended,' but instead such declarations dangerously function to 'block hearing' (56, original emphasis). She argues, "our task is not to repeat anti-racist speech in the hope it will acquire performativity $[\ldots]$ anti-racism requires interventions in the political economy" $(55)^{3}$.

Indeed, we suggest that discourses of 'equality', like 'anti-racism', can operate not as benign empty signifiers but as sponsors and producers of something else. As we show, 'equality' can be enrolled into practices of elite distinctions and closures. This does have specific performative effects, namely in constituting a depoliticised and naturalised inequality - socially and within the very 'equality projects' of service and benefaction that elite schools engage in. We suggest the dominant uses of equality work as a process of 'decontestation' (Freeden 1996). That is, struggles over alternative concepts of equality (and their political economic requisites) are made to seem unnecessary, unreasonable, unviable, or impossible. This can function to legitimise and leave unchanged the hierarchical relations of power (social, material, and intellectual) assumed by elite groups in their claims on equality-projects.

\footnotetext{
${ }^{3}$ Similarly, Reay (2012) interrogates the ways in which discourses of 'social justice' have been appropriated in British political discourse without attendant egalitarian principles or commitments to redistribution. She examines how contemporary educational discourses of diversity, choice, and social justice in Britain, 'whilst sounding progressive, positive and beneficial, have worked to sanction and exacerbate inequalities' (592).
} 


\section{Educating the new elite: some lessons in equality}

Elite education is taking new forms in India. The old elite schools that were established before colonial independence to serve the political elite and aristocracy are now competing in an expanded school market which has seen a fast-growing high-fee schooling sector catering to the 'new elite'; the 'moneyed' classes often associated with 'global' technology and business professions (Rizvi 2014). Specifically, there has been a marked growth in the international school market, with some 478 international schools across India affiliated with the UK-based Cambridge International Examination and Edexcel, and the Geneva-based International Baccalaureate Organisation (The Times of India, May 20, 2015). Our analysis of data obtained from the IBO website suggests a more than four-fold growth in the number of IB schools in India over the last decade. ${ }^{4}$ Indian Academy is one such 'new elite' school. It is a large secular private primary and secondary (Prep-12) international school on the edge of a major cosmopolitan Indian city. Its campus covers over 40 acres, with vast sporting fields and facilities, grand and imposing white-columned buildings and manicured gardens. Its website claims that the school has a 'truly world class ambience'. It is a relatively new school, having opened in 2003, but it has developed a reputation for being a high-performing educational institution in the city. The school is co-educational, with most enrolments being day-students and mainly Indian nationals. It also has boarding facilities which are primarily used by its diverse international students, including a significant Korean cohort. There are approximately 100 students per year level in the senior grades and a large teaching cadre of mostly Indian teachers.

Indian Academy does not typically serve political elites, but it has been especially attractive to transnationally-mobile business 'new elites' who are able to afford its high fees. The parents we interviewed for the study tended to work in the business and technology sectors. Many were employed by multi-national companies, and many had previously lived in the United States. Almost all Indian students were of dominant Brahmin backgrounds, as reported to us by teachers; indicative of how 'old' caste privileges are reinforced through the 'new' global knowledge economy and its educational institutions (cf. Subramanian 2015). Students described the strong boundaries between their privileged lives and the lives of the country's majority poor. We recognize the complex constitution of social privilege, but we use the term 'elite' with particular reference to participants' and our own modes of social and institutional closure, including

\footnotetext{
${ }^{4}$ The first IB school in India was established in 1976. By 2006, only 30 IB schools operate in the entirety of the country. This number has increased sharply to $123 \mathrm{IB}$ schools in India by 1 June 2016. http://ibo.org/programmes/find-an-ibschool/?SearchFields.Country=IN
} 
intersections of class, English language education, caste, urban transnational identities and international mobility. One student reflects on the spatial, embodied effects of this closure:

it's really easy to cocoon yourself because almost all of us, we live in gated communities. When we're walking around downstairs we don't see them [poor people]. When you go into school, if you don't look out the window you don't have to see anything, it's basically your choice. It's really easy to forget sometimes. A lot of people say that India's like - India's now modernising and India's this, India's that, but India is leaving a lot of people behind while it's doing all this.

The students at Indian Academy are expected to be globally mobile 'leaders' with an international outlook, and their socio-economic privileges are made normative through school cultures and practices. ${ }^{5}$ Along with these messages, the school has an explicit focus on community service and social responsibility framed by an ongoing dialogue about 'access to opportunity' and 'social change'. The school prides itself as being a pathway to elite universities, primarily Ivy League institutions. As Rizvi (2014) observes of such elite private schools in India, "common to these schools is their boast of producing graduates who are able to gain admission into the world's leading universities and who possess various 'twenty-first century skills' that the global economy demands" (Rizvi, 2014, 290-291). Almost all senior students we interviewed described their plans of studying in the US or the UK, arguably a strategy of a globally oriented 'new elite' class formation. Many students, parents and teachers articulated how this pathway was enabled by the globally-recognised International Baccalaureate (IB) curriculum, which was being used in the school across its primary and secondary programmes. The global purchase of the IB curriculum was a primary factor in parents' choice of school. Many spoke about the attraction of the school's liberal educational focus on the 'whole child' in terms of an 'all-round' development, including the arts, sport, music and languages, as well as the focus on community service. As one parent described, 'what's excellent about the IB is the community service ... especially in a place like India where you can do so much'.

According to the IB, education for international mindedness aims to develop global citizens who, 'recognizing their common humanity and shared guardianship of the planet, help to create a better and more peaceful world' (IB, 2008, 5). The school enacted the IB curriculum and its embedded ideals of international mindedness through a 'Service Leadership' programme. ${ }^{6}$ The Headmaster emphasised their holistic

\footnotetext{
${ }^{5}$ It is beyond the scope of this paper to offer a detailed analysis of the school's aesthetic, spatial and cultural production of elite distinctions. For ethnographic insights into the contemporary social aesthetics of elite schooling, see Fahey et al. (2015).

${ }^{6}$ International Mindedness is a core notion in the IB educational philosophy and the curriculum frameworks of IB programmes. Our study (Sriprakash et al. 2014) shows that IB Schools interpret and incorporate international mindedness in diverse ways. The six IB schools in our study recognised 'service' to local and global community as a practical implication of international mindedness. Across all schools, the IB's CAS (community, action and service) programme provided an important structure for
} 
approach during one of our discussions, "The IB is a philosophy, a 'way of life', it is not just about learning a curriculum. For us, international mindedness is achieved through Service Leadership". International mindedness in Indian Academy was translated as world/local leaders engaging in service. This was also reflected in the school's mission statement, which explicitly sets out the importance of being global leaders who act locally. ${ }^{7}$ The school sees all its activities - sports events, community service, academic competitions, music events, art exhibitions - as integrated into the agenda of the Service Leadership programme. For example, the theme for a student art-exhibition we viewed was 'Equality'; a publicspeaking competition focused on the environment and social justice; and songs performed in the annual music show we attended were inspired by the theme of 'leading change', and included Gandhi's popular bhajan Raghupati Raghava Raja Ram, and Imagine by John Lennon. The Service Leadership agenda, according to the Headmaster, is to encourage students to use their privilege to be 'agents of change' for the common good.

As part of its outreach agenda, the school runs the 'Indian Academy Community School' which is often called 'the equal opportunity school' by students, parents and teachers. The Community School is a small English medium school using the state curriculum and is attended by disadvantaged children in the local area. It is located adjacent to the main campus, and in contrast to the imposing white columns of the main school, the smaller community school might be characterised as having 'folk' architecture. It employs a separate team of teachers, and Indian Academy students conduct much of their community service work there, such as mentoring students, fundraising for equipment, and organising school initiatives and events. The Community School is reflective of the growth in India over the last three decades of private school outreach (Day Ashley 2005), privatised and corporatized social responsibility (Thapliyal, 2015), and upper/middle-class 'volunteerism' (Maithreyi, 2015). As Day Ashley (2005, 134) notes of educational outreach programmes in the Indian context,

international mindedness as service. However, the extent to which these programmes supported sustained change-oriented forms of service varied from school to school, and seemed much dependent on how integrated CAS was across the school's ethos and other activities. In the case of Indian Academy, service was strongly integrated throughout the school curriculum. Here leadership is foregrounded in academics, but also arts, sports, and community service. The narrative of service leadership is communicated strongly to students, and informs the school identity, from the school song to house-activities, subject areas and in particular, the outreach school. As our discussions also show, teachers demonstrated difference in how they interpreted concepts of equality, international mindedness, and service leadership. These led to different pedagogic approaches, and the IB as well as Indian Academy emphasise the need for such teacher autonomy within their frameworks, via the notion of 'Creative Teacher Professionalism' (IBO 2009).

\footnotetext{
${ }^{7} \mathrm{We}$ do not quote the mission statement in full here, in order to preserve the anonymity of the school.
} 
Despite the fact that these formerly exclusive educational institutions have started to open their doors to the socially and economically disadvantaged, the very existence of the two facilities in private school outreach: the private school and the outreach programme, indicates a segregated provision of education, even though it is under the same umbrella institution.

In the context of recent Indian and international education reform that has seen a significant growth of private enterprise and diversity of entrepreneurs acting in education, the Community School model of private responsibility for 'outreach' arguably sends an educational message that equality-projects can be effectively approached through privatised - and segregated - solutions. Indeed, Thapliyal (2015) argues that the language of rights has been co-opted into agendas of privatisation and segregation in Indian education which reaffirms elite closures (see also Khan 2012, for a discussion of the cooption of rights discourses by the elite in the USA).

The 2009 Right of Children to Free and Compulsory Education Act (RTE) requires all schools in the country, including elite private providers like Indian Academy, to have at least 25 per cent of student enrolments from "economically weaker and socially disadvantaged" groups. There has been significant resistance by private schools in taking up this highly contested requirement (see, for example Sarangapani et al. 2014, Day Ashley 2013 and Srivastava \& Noronha, 2014), and a number of schools have translated state agendas of 'rights' to education through 'outreach' arrangements. A few, but by no means most, participants at Indian Academy associated the existence of the Community School specifically with the RTE 2009 legislative requirements. More common was the broader discourse that all children have 'rights' to education, which the 'equal opportunity school' at Indian Academy was offering. Such privatised and conditional enactments of 'rights' to education - in this case the provision of a separate and substantively different 'equal opportunity school' - arguably protects elite closures and can strengthen them through claims of equality. It is to these dominant uses of equality in such contexts of elite schooling that we now turn.

\section{The uses of equality in Indian Academy}

Teachers, students and parents in Indian Academy offered different conceptions of equality when they spoke about the social and educational arrangements of their school. The analyses in the sections below focus on three dominant and interrelated conceptions of equality that emerged from our analysis of interview and observational data: (1) equality for-profit; (2) equality as deferred; and, (3) equality as a differential inclusion of the poor. We illustrate these uses of equality in the Indian Academy context, showing how they 
have particular performative effects, namely in constituting and justifying a normative inequality. We suggest this 'enterprise equality' is a mode of class-formations for the new globally-oriented elite.

\section{Equality for-profit}

A key conception of equality put forward by participants in our research is that the project of equality benefits the elite. Positioned as tools for individual gain, practices of 'international mindedness' and 'service leadership' at Indian Academy were seen to build students' curriculum vitaes to benefit college applications, contribute to students' self-development, and foster personal relations and networks. Liberal education tends to be positioned, marketed even, as 'not for profit' (Nussbaum, 2012), dissociating itself from its material base and political interests despite long being the preserve of the elite. However, there was open acknowledgement by parents, students and teachers of the profit of the 'all-round' approach of Indian Academy. Community service was frequently described as one kind of family strategy for securing entry into western elite educational institutions, and from there, positions of further socio-economic privilege. 'Service' was explicitly recognised as self-serving; a form of cultural capital for university admissions in the west. As one parent explained,

If you're trying to apply to colleges abroad, especially in the US, they don't just look at academics. It is an all-round approach. It includes sport, it includes community service, it includes whatever as a student you're able to give back to the community, no matter if it's a little contribution, it still matters a lot.

A 'not-for-profit' liberal education was understood as necessary for pursuing equality for-profit. One student reflected on the importance of community service work for his university applications, and also acknowledged 'different' forms of 'helping out' in the future:

I see community service as a big part of things [for my university applications] and obviously once I go to America [for university]... when I go there again I might see things differently and might try to help out.

Such for-profit equality work is constituted through an elite subjectivity in which students understand their position as maintaining their privileges, perhaps even in some cases becoming world and local leaders as their school desires. The project of equality for-profit enables these students to pursue their life/work/power trajectories. Indeed, students and parents recognised that such investments in equality would bring an array of personal benefits to students, like 'independence', 'resilience', 'respect' and 'confidence', which were each tied to future educational and social success. For this student, community service is one of the many paths to develop his personal confidence and leadership skills: 
I actually became a better leader after I moved here...I just felt like I could get my ideas through better. Actually the thing was, community service is one way to bring out your leadership in a person. I started doing a lot of community service... in Grade nine and ten...Then once I got to grade 11, when I felt confident about myself, I was like 'oh yeah, why don't I start something. My seniors did it, why don't I do it', and I get people who want to do it with me. So that's when I felt that I was able to portray my leadership skills. So then I initiated a few things in school, and got the backing of the school... It wasn't only community service, but also MUNs [Model United Nations] and other stuff -I was a Chair....

Self and career development has long been seen as central to service activities in education (Brewis, 2009), and here it is significant to note the particular articulation of self-development as producing elite transnational, networked 'leaders'. As this parent reflected, her son who graduated from Indian Academy and is now in the US attending university continues to profit from the networks established through service activities:

because he's met all these friends before and they've stayed friends or in touch because of different [community service] programs. It helps to build up that kind of thing and now he's abroad, now it's easier. Because you also know a few people, familiar faces, you can write to somebody for help and you get it quickly.

The profit of equality-work is the production of desired subjectivities for the successful global leader: confident, networked, and entrepreneurial. These are, arguably, ideal citizens of the neoliberal state: not only are they perceived to make few claims on the state for their own education/welfare, but they are also active in shoring up social equality as a private and profitable responsibility.

\section{Equality as deferred}

In progressive discourses on equality, equality is often considered as a general goal postponed into the distant future. Such postponers of equality might be closely familiar to us in education, given the developmental tone of much of our pedagogic work:

Their common motto is: Accept to submit your (lower) intelligence to my (higher) understanding today in order to be my equal tomorrow! Because it is based upon the principle of inequality of intelligence, this falsely emancipating (but actually stultifying) attitude, which has permeated most forms of modern progressive politics, defeats its stated purpose by relying on (and by perpetuating) the very inequality it pretends to abolish. (Deranty, 2010, 32)

The deferral of equality was seen as a necessary condition by students at Indian Academy. They often spoke about needing individual advancement, security, capital, and power, before being able to act on projects for 
equality. For example, many students we interviewed expressed their wishes to help people, but this would only become more possible after they become doctors, lawyers and successful entrepreneurs. One student said,

...I've gotten really involved in community service. Well I can't really - I'm going to be in school for 10 years because I want to be a doctor but like I really want to do more work - there's a lot of hospitals here where people provide free medical care. So I want to do an internship in one of those this summer so I can actually help out but I don't know. It's going to be a long time before I can actually do something. But maybe in the future I'll be able to do things to - and I also want to work on, you know, those organisations that provide education to students.

While this student grapples with the extent to which she can be an agent of social change, now and into the future, her uncertainties also highlight how equality can be a project that is conceptualised through deferral. This deferral is legitimised through elite narratives of becoming world and local leaders which foreground individual success. As another student expressed:

In Korea there is one idiom that if you want to be a real man you have to help poor people - my father said it ...In my opinion first I need to be satisfied in my current life... I need to get enough money and enough good thing for my family, then I can serve for my - I need - first I need to finish my college work then I can work on it.

Education projects of equality, such as Indian Academy's Community School reinforce the notion that equality is conceptualised as deferral. For example, consider the ways in which this parent discusses the role of such service activities:

so I think that part of it, when these children are exposed [to community service], in some ways they may not give immediately, but when you reach that threshold of meaningful life, you do give it back. See, we started doing it for our servants [maids]. It's because we saw our parents do it. It gets imbibed. It's what you imbibe, it's what you want to absorb. They will be givers in many ways. Who knows, maybe they will all be - they'll run a company in which they hire somebody through the Community School, who has also had the equal opportunity education. It's a possibility, isn't it?

Here, 'equality in the future' was used as a strategy for maintaining class closure by these elite participants. Their conception of equality here was to stabilise the status quo of inequality; privileged enterprising positions will be maintained by elite projects of equality ('they'll run a company'). Here, the use of equality in a context in which conditions in the political economy remain unchanged has particular performative effects: the subjectivity of elite students as future leaders is normalised and legitimised, and, equality continues to be deferred, displaced by individualised for-profit equality.

\section{Equality as differential inclusion}


The Community School established by Indian Academy provides further context for exploring how the elite determine who gets included in equality for-profit projects, or, as one teacher describes, who is 'allowed to grow'. Framed as an 'equal opportunity school', resources are provided to poor children selected into the school, but this gesture towards equality of opportunity need not be accompanied by equality of outcome, as this teacher explains:

We have this community school where it's called an equal opportunity school and they are given laptops. They are educated and after a certain age they bifurcate, depending on their talent, depending on their abilities. I think they are getting to see something beyond their own lives. But that is also allowing them to grow. I think the ones who do very well will be picked up and they will be sponsored to do IT courses and things like that.

The use of equality as differential inclusion is about who gets 'included' (or, to use the language of this teacher, who is 'allowed') into projects of equality. There is a need to account for the complexities of equality as manifested in ways of keeping people 'inside' the workings of society. The concept of differential inclusion (Mezzadra \& Neilson, 2013) is a means of explaining how 'inclusion' policies and programs can effect variable gradations of control in social and economic arrangements. Differential inclusion makes certain people the objects of 'difference' and targets them for inclusion or integration. It works to make inequalities operable within the shifting arrangements that constitute and characterise contemporary claims on equality.

The use of equality as differential inclusion often assumes the inevitable and necessary asymmetrical assimilation of the Other, against tests of everyday heterogeneity, pluralism and diversity. Subjects of equality projects described by Indian Academy students included animals, women, employees/maids, poor children, cancer-patients, and the blind. Equality as differential inclusion, or 'allowing "them" to grow', is arguably based on the presupposition of intellectual inequality (see Deranty 2010, Ranciere, 1991) which legitimises the 'reform' of the Other (see, for example, Sriprakash, 2013). In this formulation, success is when 'they' become more like 'us' - despite the class closures and structural inequalities which counter such assimilation.

What are the effects of this differential inclusion? Let us return to the teachers' description of the community school, above. Streaming (or 'bifurcation') occurs within the 'equal opportunity school' through what is seen as a meritocratic allocation ('depending on their talent, depending on their abilities'). This division and differential inclusion occurs in the labour market too, as determined (or 'sponsored' as this teacher suggests) by the elite, and as part of a seemingly ever-postponed equality. The system-wide project 
of differential inclusion via the RTE's 25 per cent provision (see above) further legitimises these discourses of meritocracy. Educational 'opportunity' is seen to have expanded in India, through mass education, and more recently through RTE places in elite schools, as well as strategies of privileged benefaction such as the Community School. When this supposed equal opportunity is combined with gross inequality of outcomes, the 'success' of individuals is attributed to their merit ('talent' and 'ability', as the teacher above explains). The disassociation of 'success' from its social and material context in turn positions the 'failure' of Others as deserving and natural. This can be especially explicit and pernicious in the Indian context in which caste is seen to ascribe social location by birth. Through the use of equality as differential inclusion, operating within an 'equal opportunities' framework, inequality of outcomes for the Other can be legitimised and made the natural order of things.

Strong social and material boundaries were recognised and maintained between the 'equal opportunity' Community School and Indian Academy by elite actors in Indian Academy, but teachers also explained strategies to weaken these boundaries as a particular feature of the school's equality work. Part of this was to encourage 'shared learning' opportunities for students across Indian Academy and the Community School, when usually lessons from the formal curriculum are conducted separately. Such opportunities were seen as particularly possible at the primary school levels, given the greater flexibility of the curriculum. However, by senior-school, teachers reported that it was more difficult for shared learning to take place between the two groups of students, not only because of their different and more strongly framed curricula, but also because of the seemingly greater divergence of academic levels between the two groups. However, such hierarchical 'difference' permeates the 'inclusive' discourses of 'shared learning' at the primary level too, and arguably works to reinforce such future divergences. Consider, for example, this teacher's description of a primary-level class in which students from both schools were brought together in a shared learning space:

So we divided into groups, and the teachers taught this curriculum about plants. Then they [students] all wrote a journal. They wrote it in a journal about gardening and the whole process of planting and how plants grow, the parts of the plant. Of course, what the community school children could write, the way they could express, was much less than what our children could. But we did a lot of diagrams and - it was learning. It was shared learning together. It wasn't like our students were the teachers and they're [the students] - no, they were all together. They were often in mixed teams doing art projects like collages, cutting and gluing. So in that playing field, everyone's equal.

In this controlled 'playing field', decisions about how such equality work is done, and who is included and excluded from this work, was determined by the teacher who had to pedagogically manage perceived and real asymmetries between students. 'Shared learning' between students from the two schools was the required performance in this playing field, but the differences in written literacy between 'community school children' and 'our children' led to pedagogic strategies of focusing on 'collages, cutting and gluing'. Here 
we see a cautious staging of a particular pedagogic activity to secure the intellectual and social hierarchy of writing over art, of the elites over the poor. Rather than learning to write in mixed teams, the children from both schools engage in art-based learning. Equality is made perceivable or imaginable through the act of learning in mixed teams, with the children from both schools seemingly reconstituted as equals. However, the playing field created by elite actors constitutes their site for signifying what equality means to them. In this case, the performative effect is equality as conditional differential inclusion which reinscribes intellectual hierarchies that are part of elite class formation, and has real effects on educational outcomes.

\section{Concluding Thoughts: 'Enterprise equality' and its contestability}

Do these examples of elite uses of equality close down the possibility of 'equality' as a project that can be undertaken by the elite? Here the questions raised by Kenway and Fahey (2015) about the possibility of 'absolute altruism' in the elite school context come back to the fore. We suggest, as Hildebrand and Martell $(2012,204)$ argue, that 'struggles, conflicts, divisions on all social levels are irresolvable, now and forever', so the aim is not final reconciliation, nor a nihilistic suspension of the political, nor 'absolute altruism'. Rather, a project of equality is one that needs to proceed as 'an indeterminable struggle over the contingent institution of the social' (ibid, 198). Indeed, as Butler writes in her dialogue with Ernest Laclau (1997) on The Uses of Equality, 'it seems that the notion of equality would proceed undemocratically if we claim to know in advance who might make use of its claim, and what kinds of issues fall within its purview' (5). This is, put simply, to present educational projects of equality, like community service, as ever-present antagonisms. The contestability of equality is its necessary condition. This has pedagogic implications, as one teacher at Indian Academy compelled us to consider. Departing from the dominant uses of equality that we outlined above, the teacher was explicit about the need for us all to re-contest the idea of equality:

equality for me is a framework for coexistence created by a few elites of the upper class of this society... if you think about it, we have two people coming to our house to work. One is a maid cleaning the house and one is the cook. ... This guy, the cook, he actually loves me. How equal is he? His equality is getting determined by me.

This teacher underscores the power relations in the material and social bases of any project of equality. It works to dispute flattened versions of equality that are premised on pluralism and sameness. The teacher goes on to suggest equality is an 'illusionary framework for coexistence'. Reflecting on the very process of our interview, he says of the illusion:

what I am saying is that you are equal to me...we are sitting over here and talking...but you determine my equality, isn't it? Today we are talking, right....but maybe in a seminar if you 
are there as a university professor and I'm just a small time school teacher. You're going to determine my equality.

Here, there is an acknowledgement that the 'elite' (whether that is me, Arathi, the interviewer and academic, or this teacher as a person who employs a cleaner and a cook) 'do' equality by maintaining material, social, and intellectual hierarchies. This interrogates the normative inequality on which projects of service in elite schools, everyday relations beyond schools, as well as our own research endeavours, can be based. As one student explained, doing equality through the maintenance of hierarchies is 'easy'. It is 'easy' for students at Indian Academy to be the good citizens of the community service paradigm, more so than poor students in disadvantaged school, because 'the opportunities here are abundant to get involved in this act'. The harder task at hand is how intellectual, social and material hierarchies can be contested through such acts.

Indeed, this points to the importance of the pedagogic project behind programmes like community service and international mindedness: it must not paper over or 'settle' the contestability of equality. As Hildebrand \& Martell $(2012,202)$ reflect on the educational project of democratic citizenship, 'rather than presenting itself as an ideological block with clear-cut and unquestionable truths, a democratic project should function as surface for the inscription of a huge variety of emancipatory struggles. Its capability of questioning the given status is an ever-present chance'. We argue that the socio-material conditions of equality and its contestations must not be papered over in elite schools - and beyond - through discourses that position equality as for-profit or postponed or as a means for differential inclusion. Always-contested equality projects like community service and global citizenship need to encourage debate and action about the conditions "that would allow "saying" to "do" what it says".' (Ahmed 2004, 54). These are the political economic conditions of equality-claims in education. It is worth remembering, as Warmington $(2015,274)$ argues, that 'educational campaigns alone will not erase poverty; only economic and political attention to welfare and wages can do that.' To be sure, there is a role here for the world/local leaders of our research, as well as us, but not one without struggle and indeterminacy. Otherwise it is the contestability of equality that is at stake.

The purpose of this analysis has not been to criticise the activities of a particular school, or the curricular programmes of the IB, but to highlight how contemporary approaches to persisting issues of inequality are being shaped by specific national cultures of neoliberalism that carry global significance too. Our analysis has revealed how a form of what we call 'enterprise equality' is produced and performed through discourses and structures of service and benefaction among young elites in India; equality is legitimised as for-profit, as deferred, and based on conditional differentiated inclusion. Such uses of equality draw on and feed into the cultures of contemporary Indian entrepreneurialism and global capitalism which, in the context of aggressive 
privatisation of educational services and 'expertise', position the struggle for 'equality' as uncontestably a matter for the private actor instead of the democratic state. We argue that enterprise equality is a strategy of class formation for the new elite. In India and beyond, when the elite emerge as the winners in such struggles, our advantageous positions are easily perceived as deserved and meritorious, despite the fact the game has been played by our own rules. Contesting this version of 'equality' is the political and pedagogic challenge of our time.

\section{Acknowledgements}

This work was conducted under a research grant supported by the IB.

\section{References}

Ahmed, S. 2004. "Declarations of Whiteness: The Non-Performativity of Anti-Racism." Borderlands E-journal 3 (2). http://www.borderlandsejournal.adelaide.edu.au/vol3no2_2004/ahmed_declarations.htm.

Ashley, L. D. 2005. "From Margins to Mainstream: Private School Outreach Inclusion Processes for Out-of-school Children in India." International Journal of Educational Development 25 (2): 133-144.

Ashley, L. D. 2013. "The Shifting Politics of the Private in Education: Debates and Developments in Researching Private School Outreach in India." Comparative Education 49 (2): 206-225.

Brewis, G. 2009. "From Working Parties to Social Work: Middle-class Girls' Education and Social Service 1890-1914." History of Education 38 (6): 761-777.

Butler, J., E. Laclau, and R. Laddaga. 1997. "The Uses of Equality." Diacritics 27 (1): 2-12.

Daloz, J-P. 2012. The Sociology of Elite Distinction: From Theoretical to Comparative Perspectives. London: Palgrave Macmillan.

Deranty, J-P. 2014. Jacques Rancière: Key Concepts. London: Routledge.

Fahey, Johannah, Howard Prosser, and Matthew Shaw, eds. 2015. In the Realm of the Senses: Social Aesthetics and the Sensory Dynamics of Privilege. Dordrecht: Springer.

Fernandes, L., and P. Heller. 2006. “Hegemonic Aspirations: New Middle Class Politics and India's Democracy in Comparative Perspective". Critical Asian Studies 38 (4):495-522.

Freeden, M. 1996. Ideologies and Political Theory: A Conceptual Approach. Gloucestershire: Clarendon Press.

Gooptu, Nandini, ed. 2013. Enterprise Culture in Neoliberal India: Studies in Youth, Class, Work and Media. Abingdon: Routledge.

Government of India. 2009. The Right of Children to Free and Compulsory Education Act, 2009. New Delhi: Ministry of Human Resource Development.

Hey, V. 2006. "The Politics of Performative Resignification: Translating Judith Butler's Theoretical Discourse and Its Potential for a Sociology of Education." British Journal of Sociology of Education 27 (4): 439-457.

Hildebrand, M., and L. M. Conrad. 2012. "The Negation of Power: From Structuration Theory to the Politics of the Third Way." Distinktion: Scandinavian Journal of Social Theory 13 (2): 187-207.

IBO (International Baccalaureate Organisation). 2008. Towards a Continuum of International Education. The Hague: IBO.

IBO (International Baccaulareate Organisation). 2009. The Diploma Programme: A basis for practice. Cardiff: IBO 
Kenway, J., and A. Koh. 2015. "Sociological Silhouettes of Elite Schooling." British Journal of Sociology of Education 36 (1): 1-10.

Kenway, J., and J. Fahey. 2015. "The Gift Economy of Elite Schooling: The Changing Contours and Contradictions of Privileged Benefaction." British Journal of Sociology of Education 36 (1): 95-115.

Khan, S. R. 2011. Privilege: The Making of an Adolescent Elite at St. Paul's School. Princeton: Princeton University Press.

Khan, S. R. 2012. "Elite Identities." Identities 19 (4): 477-484.

Kumar, K. 2012. "The Pedagogy Market." Economic and Political Weekly. xlvil (47):18-48.

Lukose, R. A. 2009. Liberalization's Children: Gender, Youth, and Consumer Citizenship in Globalizing India. Durham: Duke University Press.

Maithreyi, R. 2015. “Reconceptualising Life Skills Education: A Critical Analysis of Ideas around Childhood, 'Risks' and 'Success". Unpublished PhD diss., Manipal University.

Mehendale, A., R. Mukhopadhyay, and A. Namala. 2015. "Right to Education and Inclusion in Private Unaided Schools." Economic \& Political Weekly 50 (7): 43-51.

Mezzadra, S, and B. Neilson. 2013. Border as Method, or, the Multiplication of Labor. Durham: Duke University Press.

Mukul, Akshaya. 2015. "International Baccalaureate Schools in India Post 10-fold Growth in 10 Years." The Times of India, May 20. http://timesofindia.indiatimes.com/home/education/news/International-Baccalaureateschools-in-India-post-10-fold-growth-in-10-years/articleshow/47349322.cms

Nambissan, G. B., and S. J. Ball. 2010. "Advocacy Networks, Choice and Private Schooling of the Poor in India." Global Networks 10 (3): 324-343.

Nussbaum, M. C. 2012. Not for Profit: Why Democracy Needs the Humanities. Princeton: Princeton University Press.

Radhakrishnan, S. 2011. Appropriately Indian: Gender and Culture in a New Transnational Class. Durham: Duke University Press.

Rancière, J. 1991. The Ignorant Schoolmaster: Five Lessons in Intellectual Emancipation. Stanford: Stanford University Press.

Reay, D. 2012. "What Would a Socially Just Education System Look Like? Saving the Minnows from the Pike." Journal of Education Policy 27 (5): 587-599.

Rizvi, F. 2014. "Old Elite Schools, History and the Construction of a New Imaginary." Globalisation, Societies and Education 12 (2): 290-308.

Sarangapani, P., A. Mehendale, R. Mukhopadhyay, and A. Namala. 2014. Inclusion of Marginalised Children in Private Unaided Schools under the Right of Children to Free and Compulsory Education Act, 2009. New Delhi:

Oxfam India. http://www.oxfamindia.org/sites/default/files/wp-inclusion-of-marginalised-children-inprivate-unaided-schools-190314-en 0.pdf

Sriprakash, A. 2013. New learner subjects? Reforming the rural child for a modern India. Discourse: Studies in the Cultural Politics of Education, vol 34, no 3, pp 325-337.

Sriprakash, A., Singh, M., Qi, J. (2014) A Comparative Study of International Mindedness in the IB Diploma Programme in Australia, India, and China. US: International Baccalaureate Organisation. Retrieved from: http://www.ibo.org/globalassets/publications/ib-research/dp/international-mindedness-final-report.pdf Accessed 26/07/2106.

Srivastava, Prachi., and Claire. Noronha. 2014. "Early Private-School Responses to India's Right to Education Act: Implications for Equity." In Education, Privatisation and Social Justice: Case Studies from Africa, South Asia and South East Asia, edited by lan Macpherson, Susan Robertson, and Geoffrey Walford, 179-198. Oxford: Symposium Books.

Subramanian, Ajantha. 2015. "Recovering Caste Privilege: The Politics of Meritocracy at the Indian Institutes of Technology." In New Subaltern Politics: Reconceptualizing Hegemony and Resistance in Contemporary India, edited by Alf Gunvald Nilsen, and Srila Roy, 76-99. New Delhi: Oxford University Press.

Thapliyal, Nisha. 2015. "Privatized Rights, Segregated Childhoods: A Critical Analysis of Neoliberal Education Policy in India." In Politics Citizenship Rights, edited by Kirsi Kallio, Sarah Mills, and Tracey Skelton.1-13. Singapore: Springer.

van Zanten, Agnès. 2009. "The Sociology of Elite Education." In The Routledge International Handbook of the Sociology of Education, edited by Michale W. Apple, Stephen J. Ball, and Luís Armando Gandin, 329-339. London: Routledge.

Vidya, K. S., and P. Sarangapani. 2011. “Is Education News?" Economic Political Weekly. xlvi (42): 69-76. 
Vincent, Carol, and Menon, Radhika. 2011. "The Educational Strategies of the Middle Classes in England and India." In Education and Social Justice in the Era of Globalisation: Perspectives from India and the UK, edited by Marie-Carine Lall, and Geetha Nambissan, 56-80. New Delhi: Routledge.

Watt, C.A (2005) Serving the nation: cultures of service, association, and citizenship in colonial India. Oxford: Oxford University Press. 